\title{
Availability and Accessibility of Geographic Information Systems in Nigerian Federal Universities of Technology Libraries
}

\author{
by \\ MUSA, Hussaini and Ptijjani Abubakar
}

\begin{abstract}
This study was carried out to investigate the Availability and Accessibility of Geographic Information Systems in Nigerian Federal Universities of Technology Libraries. Three research questions were formulated. Survey research design was used for this study. The overall total number of 1422 respondent including students, faculty staff (GIS users) and librarians were drawn as population and as sample size of the study, from Federal University of Technology, Akure, Minna, Owerri and Abubakar Tafawa Belewa University, Bauchi. Two set of questionnaire were used to collect data for this study one for the GIS users and another for the Librarians. The data collected were presented and analyzed using frequency distribution table and percentages. The study found among others that there are computer hardware units for GIS operation, though some peripherals like plotters, scanner were less available among the selected Nigeria FUTs, ArcView was the type of GIS software that were available for GIS operations. This study concluded that GIS services will be better utilized if they are brought into the library which is the information hub of the university. Lastly, it was recommended that the university library should collaborate with organizations that deal with spatial information or GIS related departments in the university to facilitate GIS services integration into the array of library services.
\end{abstract}

\section{Introduction}

Maps have been around since the dawn of mankind. Traditionally, geographic information has been represented in terms of maps, charts, atlases, globes etc. Knowledge and memory of location and navigational abilities are fundamental to animals and mankind. Looking at maps, our questions are answered by establishing geographic relationship with them; we plan our trips, tours, hike and decide locations, places of visit on the basis of maps and charts. Geographic Information System (GIS) is the merging of cartography, statistical analysis, and database technology. GIS systems are used in cartography, remote sensing, land surveying, public utility management, natural resources management, photogrammetric, geography, urban planning, emergency management, navigation and localized search engine. Application of GIS may allow emergency planners to easily calculate emergency response time and movement of response resource (for logistics) in case of natural disaster; GIS may be used too to find wetland that need protection strategies regarding pollution; or GIS can be used by a company to site a new business location in response to a previously under served market (Goodchild, 2010).
GIS has been used mostly by geographers, but the 1990's saw a few events that paved way for wider application and usage by different professionals. First, the Government Printing Office started distributing data in machine-readable form. Next, the development of affordable desktop GIS applications made the technology widely available (Deckelbaum \& Bruman, 1999; Soete, 1997). The American Association of Research Libraries stepped up to the plate and partnered with the largest GIS vendor, Environmental Systems Research Institute (ESRI) and other commercial providers to create the ARL GIS Literacy Project to bring GIS to libraries (Cheverie, 1995; Stone, 1999).

In Nigeria the development of GIS education and training was pioneered at the University of Ibadan in 1996 with the establishment of the first GIS Laboratory and the introduction of a graduate programme at the Professional Master's level in the country (Rasheed, 2005). This development was in response to the University Development Linkages Programme (UDLP) sponsored by the United States Agency for International Development (USAID) to help universities in the United States develop and implement a variety of long term sustainable relationships with institutions in developing countries (Rasheed, 2005). 
The adoption of GIS into regular library services in Nigeria has been slow in non-research libraries. Presently GIS are hidden away in departments where there are used solely by those with knowledge and skills and support for new users are not available. Students from other departments need GIS not just for reference but to enhance their research work. Boisse and Larsgaard (1995) pointed out that GIS is a service increasingly in demand by users of academic libraries, and if libraries fail to provide this service they will be marginalized by the academic community. GIS also provides exciting opportunities: its potentials exist in virtually all subject disciplines hence the need for the library to make available these services to its numerous patrons.

\section{Nigerian Federal University of Technology}

The drive by the Government of Nigeria to create universities that specialized in producing graduates with practical as well as theoretical knowledge of technologies led to the establishment of federal universities of technology in Nigeria. This group of universities established between 1980 and 1998 are collectively referred to as the third generation universities (National Universities Commission, 1992). These universities are:

1. Federal University of Technology, Abeokuta. (Now University of Agriculture, Abeokuta).

2. Federal University of Technology, Akure.

3. Federal University of Technology, Bauchi (Now Abubakar Tafawa Balewa University).

4. Federal University of Technology, Makurdi (Now University of Agriculture, Makurdi).

5. Federal University of Technology, Minna.

6. Federal University of Technology, Owerri.

7. Federal University of Technology, Yola.

The above seven universities as established by law, have libraries that are headed by university librarians who are principal officers. They have faculties such as science and science education, earth and mineral science, environmental technology, engineering and engineering technology, agriculture and agricultural technology, which offer courses that are relevant to or required the use of spatial information for efficiency and relevance.

\section{Statement of the Problem}

The proliferation of digital geo-references data from both the public and private sectors and its importance as information resources for processing of geo-spatial data such as mapping, maintaining of geospatial data, monitoring and planning of environmental resources, has brought changes considerably from the traditional techniques of handling geographic information to modern techniques of remote sensing and geographical information systems. As the nation's apex science and technology universities, one would expect that every innovation of modern technology or facilities such as the GIS would be available in the university libraries for wider accessibility and utilization.

Despite the availability of the GIS services in some departments of the universities under study, they are not easily accessible to the numerous users of the university libraries as a result of policies guiding their usage. Hence library users are still coming back to the library for the services but what they always get from the library is the traditional paper based maps, globes, atlases etc, and not the modern automated GIS services. The traditional Geographic Information Systems are not adequate to meet the needs of the users in this contemporary era. Mohammed (1987) observed that for the library to be effective it has to have adequate and up-to-date information resources. The relevance of the federal university libraries as the information hub is likely to reduce when they exclude vital information resources like the GIS from the library.

\section{Research Questions}

This study is to provide answers to the following questions:

1. To identify GIS services and facilities available in Federal Universities of Technology in Nigeria

2. How accessible is GIS services in Federal Universities of Technology in Nigeria

3. What is the level of awareness of GIS among the librarians in the Federal Universities of Technology in Nigeria?

\section{Research Method Adopted for the Study}

Survey method was used in the conduct of this study. The population of this study comprises the federal universities of technology in Nigeria. The subjects of the study comprised all the librarians, their divisional heads, and unit heads. A survey of the population of the study indicated that there are 89 librarians. The study adopted a purposive sampling technique to draw samples from four out of the seven federal universities of technology in Nigeria under study. These include the Federal University of Technology, Akure; Abubakar Tafawa Balewa University, Bauchi; Federal University of Technology, Minna; and Federal University of Technology, Owerri. 
The respondents included the entire 51 Librarians from the four selected Federal Universities of Technology under study. But for the academic staff in the departments, the researcher selected $30 \%$ as the sample size which gave a total of 121 Academic staff from a population of 399 from the four selected universities of technology. The instruments used in gathering data for this study was questionnaire.

\section{Review of Related Literatures}

Geographic Information Systems is used to make maps, it has the capability of "managing geographic feature location data and data related to those features" also prove to be a powerful utility (Cox \& Gifford, 1997). GIS services and data delivery may include data acquisition (creation, download, or purchase), data processing and analysis, data distribution, data maintenance, data archiving (institutional repositories), GIS applications (development and/or implementation), software (purchasing, licensing, distribution, and installation), hardware support, teaching, research, and consulting (Aufmuth, 2005). Through development of userfriendly desktop applications, GIS seems to be everywhere. In recent years, as the popularity of Geographic Information Systems grows and demand for applications and data related to it increases, more and more libraries offer GIS among their repertoire of services.

\section{Geographic Information System Services in Libraries}

Foremost among institutions offering GIS services are academic libraries. At last count in 2001, the American Association of Research Libraries listed 100 institutions as participants in its GIS Literacy Project. The institutions are primarily composed of academic libraries (ARL/GIS Participant Roster, 2001). The project aims to promote GIS services and "to address diverse user information needs." One of the needs for GIS use is spatial data. Libraries providing GIS services must provide access to spatial data resources. The real initiative started with the development of the ARL/GIS Literacy Project in June 1992. This project evolved when the Association of Research Libraries (ARL), in partnership with the Environmental Research Science Institute (ERSI), decided to develop GIS programs in various libraries. The project was very successful and now most of the major academic libraries in the United States and Canada are providing GIS services in their libraries. The introduction of GIS service in the libraries has created a new profession called the GIS librarian. The main role of this profession is to collect, store, manage and provide access to geospatial data (Adler, 2004).

(Derksen et al, 2007) posits that Stanford's Branner Earth Sciences Library and Map Collections added GIS to its services and outlined the types of GIS services being offered as:

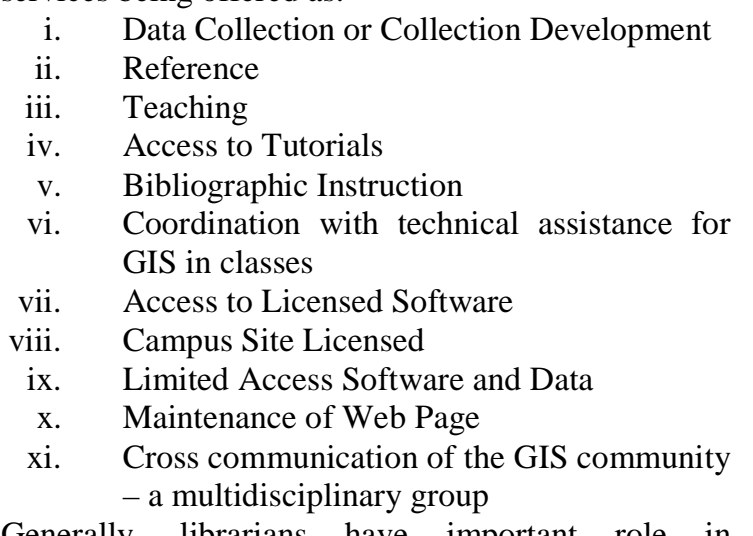

Generally, librarians have important role in facilitating academic and scientific research and instruction. They apply their knowledge and skills in the collection, archiving and cataloguing of geographical collections for easy accessibility and use of spatial information. Gabaldon and Repplinger (2006) noted that GIS has the ability to display physical attributes so that they in association with their spatial locations have changed the way in which the attributes can be viewed. He stressed that the opportunities available for analyzing them and for creating new connections and their potentials exist in virtually all disciplines. The Librarian who adroitly uses GIS techniques will have increased opportunities to access and incorporate large amount of spatial data published only in digital form. It is apparent that the growing quantity of digital spatial data is phenomenal and more geographical information is available today in digital format than on paper. For some users, this means greater empowerment but for others there is a risk of isolation (Abbot and Carolyn, 1995).

By installing one or more public access GIS workstations, the library can also facilitate GIS literacy, while enabling productive use of the data collection equipment such as high end personal computers and printers will be provided, a high capacity hard disk drive, a high-speed CD-ROM player and data compression software, wide range of colour and black and white printer available which vary in price, speed 
and output capacity. McGlamery (1995) posited that libraries through their own deliberate development of the computerized GIS technology and services or through participation in GIS literacy project or programmes can provide librarians with more specialized knowledge of GIS and geospatial data that is required to support a distribution system. Libraries providing GIS services must identify, purchase and keep up-to-date the GIS and mapping software which they choose to support.

There are a few libraries that have been using GIS or collecting digital geospatial data for several years, which many other libraries aspire to emulate. Weimer and Reehling (2006) defined an area of specialization within academic librarianship which they dub "Geographic Information Librarianship (GIL) and conceive of as a merging of traditional map librarianship. They both broadly define GIL as "Professions of providing geographic information resources and services in a library setting and identified the following three areas of expertise within this profession; (1) Cartographic materials cataloguing (2) Print map librarianship and (3) GIS librarianship. For example, Suh and Lee (1999) provided a historical background about how GIS was implemented and how current GIS services operate at Washington State University. Larsgaard (1998) talked about materials that can be easily obtained in both digital and traditional formats: reference and thematic maps of the world, maps of continents and nations, topographic maps of the world, world atlases, state atlases, aerial photos, monographs and serials; as well as outline and basemaps.

\section{Accessibility of GIS in Universities}

As universities move to using GIS, they may be faced with challenges of learning digital map concepts GIS and digital map concepts are not always easy to understand. It takes the assistance of a well trained technician to maintain and one or more staff who are skilled in the use of the software. A skill that comes only from training in the software but also from regular use of the software and the data sources, technical and GIS expertise of the staff should be also considered when developing GIS service (Howser \& Callahan 2004). The universities venturing to the far end of continuum-full featured GIS service will require staff to have advance computer and geography/cartography education. This advanced education is needed to function properly.

A survey of information science in Nigeria reveals a catalogue of problems and gaps. These include a towering infrastructural inadequacy, seemingly insurmountable problems of human and financial resources, lack of access to necessary information and resources for learning, and poor communication among key players in the library schools. The most acute problem arises from an erratic power supply. Personal computer users are the greatest sufferers as very often they cannot justify spending large sums of money (sometimes more than the cost of the computers themselves) on stabilizers and uninterruptible power supply. The depth of frustration when the power supply fails three or four times within a two-hour session or remains down for an hour, or for a whole day, has to be experienced to be appreciated.

Making information accessible and easy to understand is the goal of libraries everywhere. A geographic information system (GIS) links databases to maps, present information in ways that spark greater understanding of places and events around the globe. It allows users to view, understand, question, interpret, and visualize data in ways simply not possible with the rows and columns of a traditional spreadsheet. And, with data on a map, users can ask more questions. Users can ask "Where?" "Why?" and "How?" all with the location information on hand.

The chief role and function of a map cataloguing librarian is to create and maintain bibliographic access to all cartographic resources, hard copy and digital of the collections he/she work with. Larsgard \& Larry (1995) posited that the purpose of spatial data and creation of web pages, like that of catalogue is to make items available for use in an efficient and effective way. Activities include descriptive cataloguing, classification of items, ensuring appropriate subject access, maintaining authorized headings and keeping abreast of ever- changing national and international standards when required. Goodchild (1998) said the library being the principal means whereby citizens gain access to the services of distributed geolibraries when material is georeferenced, there is a clear advantage to locating its digital version on a server close to or within the geographic footprint of the material, since that is where interest in it is likely to be highest. Mcglamery (1995) observed that university of Connecticut generously distributed local data sets to build a GIS and mapping system, making these data accessible and usable to a wide range of consumers, both locally and beyond.

\section{Discussion of Finding and Analysis}

Frequency table and percentage were used to analyze the data collected from the various respondents. The 
data was assembled, coded, tabulated and analyzed item by item using percentage as shown below:

GIS Facilities Available in the Federal Universities of Technology in Nigeria

Table 1 shows responses as to GIS facilities that were available in the selected FUTs in Nigeria.

TABLE 1: GIS Facilities In Selected FUT In Nigeria

\begin{tabular}{|c|c|c|c|c|c|c|c|c|c|c|}
\hline \multirow{2}{*}{$\begin{array}{l}\text { S/no. } \\
\text { GIS Facilities } \\
\text { Computer Hardware units }\end{array}$} & \multicolumn{2}{|c|}{ FUT Akure } & \multicolumn{2}{|c|}{$\begin{array}{l}\text { ATBU } \\
\text { Bauchi }\end{array}$} & \multicolumn{2}{|c|}{ FUT Minna } & \multicolumn{2}{|c|}{$\begin{array}{l}\text { FUT } \\
\text { Owerri }\end{array}$} & \multicolumn{2}{|c|}{ Total } \\
\hline & $\mathbf{F}$ & $\%$ & $\mathbf{F}$ & $\%$ & $\mathbf{F}$ & $\%$ & $\mathbf{F}$ & $\%$ & $\mathbf{F}$ & $\%$ \\
\hline Computer & 208 & 94.1 & 311 & 93.4 & 316 & 95.9 & 291 & 87.7 & 1126 & 93.8 \\
\hline GPS Unit & 163 & 73.8 & 146 & 43.8 & 179 & 53.9 & 171 & 51.5 & 659 & 54.9 \\
\hline Plotter & 140 & 63.3 & 132 & 39.6 & 63 & 19 & 148 & 44.6 & 483 & 40.2 \\
\hline Printer & 81 & 36.7 & 169 & 50.8 & 191 & 57.5 & 133 & 40.1 & 574 & 47.8 \\
\hline Scanner & 33 & 14.9 & 87 & 26.1 & 87 & 26.2 & 69 & 20.8 & 276 & 23 \\
\hline Server & 194 & 87.8 & 290 & 87.1 & 295 & 88.9 & 244 & 73.5 & 1023 & 85.2 \\
\hline \multicolumn{11}{|l|}{ Software packages } \\
\hline ArcView & 183 & 82.8 & 216 & 64.9 & 263 & 79.2 & 314 & 99.7 & 976 & 81.3 \\
\hline ArcGIS & 73 & 33.0 & 63 & 18.9 & 77 & 23.2 & 96 & 30.5 & 309 & 25.8 \\
\hline ArcInfo & 94 & 42.5 & 81 & 24.3 & 65 & 19.6 & 74 & 23.5 & 314 & 26.1 \\
\hline ArcExporer & 112 & 50.7 & 221 & 66.4 & 261 & 78.6 & 211 & 67 & 805 & 67.0 \\
\hline Googlemap/Google earth & 183 & 82.8 & 176 & 52.9 & 195 & 58.7 & 179 & 56.9 & 733 & 61.0 \\
\hline Community 2020 & 64 & 29 & 41 & 12.3 & 57 & 17.2 & 83 & 26.3 & 245 & 20.4 \\
\hline MapArt /Adobe & 77 & 34.8 & 81 & 24.3 & 117 & 35.2 & 131 & 41.6 & 406 & 33.8 \\
\hline Spatial \& Image analyst & 32 & 14.5 & 27 & 8.1 & 41 & 12.3 & 132 & 41.9 & 232 & 19.3 \\
\hline LandView IV & 43 & 19.5 & 23 & 6.9 & 64 & 19.3 & 71 & 22.5 & 201 & 16.7 \\
\hline GRASS & 149 & 67.4 & 181 & 54.4 & 217 & 65.4 & 289 & 91.7 & 836 & 69.6 \\
\hline \multicolumn{11}{|l|}{ Staff/Employee who man GIS } \\
\hline Professional staff & 63 & 28.5 & 169 & 50.8 & 165 & 49.7 & 171 & 54.2 & 568 & 47.3 \\
\hline Para Professional & 138 & 62.4 & 217 & 65.2 & 277 & 83.4 & 294 & 93.3 & 926 & 77.1 \\
\hline Student with some knowledge of GIS & 5 & 2.3 & 174 & 52.3 & 62 & 18.7 & 16 & 5.1 & 257 & 21.4 \\
\hline Full time employees & 171 & 77.4 & 253 & 76 & 311 & 93.7 & 283 & 89.8 & 1018 & 84.8 \\
\hline Part time employees & 125 & 56.7 & 168 & 50.5 & 45 & 13.6 & 14 & 4.4 & 352 & 29.3 \\
\hline \multicolumn{11}{|l|}{ Frequency distribution of Available GIS } \\
\hline Aerial photography & 31 & 14.0 & 94 & 28.2 & 43 & 13 & 51 & 16.2 & 219 & 18.2 \\
\hline Attribute data & 163 & 73.8 & 174 & 52.3 & 217 & 65.4 & 216 & 68.6 & 770 & 64.1 \\
\hline Raster data format & 141 & 63.8 & 213 & 64 & 251 & 75.6 & 221 & 70.2 & 826 & 68.8 \\
\hline Vector data format & 63 & 28.5 & 59 & 17.7 & 84 & 25.3 & 82 & 26.0 & 288 & 24 \\
\hline $\begin{array}{l}\text { Remote sensing and satellite Imagery } \\
\text { data format }\end{array}$ & 79 & 35.7 & 181 & 54.4 & 195 & 58.7 & 139 & 44.1 & 594 & 49.5 \\
\hline Map data format & 203 & 91.9 & 314 & 94.3 & 313 & 94.3 & 291 & 92.4 & 1121 & 93.3 \\
\hline Graphics & 186 & 84.7 & 173 & 52 & 148 & 44.6 & 159 & 50.5 & 666 & 55.5 \\
\hline
\end{tabular}


Table 1 indicates that $316(95.9 \%)$ respondents from FUT, Minna were aware of the availability of computer units for GIS services. For servers, printers, and GPS units, 295 (88.9\%), 191 (57.5\%) and $179(53.9 \%)$ respondents respectively indicated awareness of their availability for services. There was general high awareness about the availability of the above GIS components at FUT, Minna. However, for plotters and scanners there was low awareness as only $63(19 \%)$ and $87(26.2 \%)$ respondents respectively had this awareness. The level of awareness for GIS facilities differed in the remaining universities too. For example, at FUT, Akure, the awareness of plotters recorded a high response of 140 $(63.3 \%)$ and a low response of $33(14.9 \%)$ for scanners.

With regard to all the four universities of technology studied, a total of $1126(93.8 \%)$ respondents indicated the availability of computers for GIS services. This finding is contrary to the observation of Mohammed (2006) that most of the Departments at the Ahmadu Bello University, Zaria hardly had facilities like computers, internet connectivity and related network facilities for teaching and research. It was a different situation five years after this observation because in all the universities studied, the facilities were readily available. Overall, the availability of computers was closely followed by those of servers and GPS units with 1023 (85.2\%) and $659(54.9 \%)$ responses respectively. The availability of printers, plotters and scanner recorded $574(47.8 \%), 483(40.2 \%)$ and $276(23 \%)$ responses respectively in all the universities studied. That the last three facilities were little known to be available could be due to more restricted access to them.

In terms of GIS software package availability, Environmental System Research Institutes (ESRI) ArcView recorded 976 (81.3\%) responses, and Geographic Resources Analysis Support System (GRASS), $836(69.6 \%)$ responses, which were the highest. However, Community 2020 recorded 245
(20.4\%); Spatial Image Analyst, 232 (19.3\%); ArcInfo, 314 (26.1\%); and ArcGis, 309 (25.8) responses respectively, which ranged between the medium and lowest responses among GIS users from the selected FUT in Nigeria. This finding is in line with the position of Abumere, Areola and Ajayi (1997) who posited that higher education in the developing tropical Africa was lacking the funds to purchase the necessary hardware and soft ware for GIS development. The available GIS data with the highest responses were mapping data format and raster data format, each of which attracted 1121 (93.3\%), and $826(68.8 \%)$ response respectively. The available data with the lowest responses were aerial photography data and vector data with 219 (18.2\%) and $288(24 \%)$ respectively. The finding on availability of GIS data as reported in this study is in agreement with the position of Stone (1999) who discovered that there was an overwhelming amount of GIS data that were available daily.

GIS staffing in their university, which on the general note full-time employee $1018 \quad(84.8 \%)$, and paraprofessionals $926(77.1 \%)$ recorded higher score as the nature of staff who man GIS services in the selected schools. While part-time employee and students with some knowledge of GIS attracted between $352(29.3 \%)$ and 257 (21.4\%) respondent respectively, the implication of this is that most of the selected schools have full-time staff available to man the GIS services in their respective school. This finding disagreed with Fabiyi (2001) who affirmed that the lack of expertise have limited full fledge of implementation of GIS service in Nigeria.

From the forgoing, GIS is not the software, the hardware, the database or the people, rather it is an integration of all these for the purpose of improving decision making in earth related issues. A reasonable combination of the components will represent a tremendous tool for GIS service in the selected Federal Universities of Technology. 
The GIS Services Available in the Selected Federal Universities of Technology in Nigeria

Table 2 shows the types of GIS services available in the selected Federal Universities of Technology.

Table 2: Frequencies Of GIS Services In Selected Federal Universities Of Technology

\begin{tabular}{|c|c|c|c|c|c|c|c|c|c|c|c|}
\hline \multirow[b]{2}{*}{ S/no. } & \multirow[b]{2}{*}{ GIS Services } & \multicolumn{2}{|c|}{ FUT Akure } & \multicolumn{2}{|c|}{$\begin{array}{l}\text { ATBU } \\
\text { Bauchi }\end{array}$} & \multicolumn{2}{|c|}{ FUT Minna } & \multicolumn{2}{|c|}{ FUT Owerri } & \multicolumn{2}{|l|}{ Total } \\
\hline & & $\bar{F}$ & $\%$ & $\mathrm{~F}$ & $\%$ & $\mathrm{~F}$ & $\%$ & $\mathrm{~F}$ & $\%$ & $\mathrm{~F}$ & $\%$ \\
\hline 1 & Digitizing & 213 & 96.4 & 323 & 97 & 293 & 88.3 & 298 & 94.6 & 1127 & 93.8 \\
\hline 2 & Image geo-referencing & 84 & 38.0 & 79 & 23.7 & 93 & 28.0 & 59 & 18.7 & 315 & 26.2 \\
\hline 3 & Spatial analysis & 16 & 7.2 & 41 & 12.3 & 19 & 5.7 & 21 & 6.7 & 97 & 8.0 \\
\hline 4 & GIS mapping & 216 & 97.7 & 317 & 95.2 & 305 & 91.9 & 243 & 77.1 & 1081 & 90.0 \\
\hline 5 & GIS training & 121 & 54.8 & 182 & 54.7 & 215 & 64.8 & 187 & 59.4 & 705 & 58.7 \\
\hline 6 & Remote sensing & 92 & 41.6 & 59 & 17.7 & 49 & 14.8 & 73 & 23.2 & 273 & 22.8 \\
\hline 7 & Data collection/conversion & 217 & 98.2 & 305 & 91.6 & 279 & 84.0 & 264 & 83.8 & 1065 & 88.7 \\
\hline 8 & $\begin{array}{l}\text { Link application of computerized } \\
\text { site map, aerial photograph and } \\
\text { satellite image }\end{array}$ & 10 & 4.5 & 3 & 0.9 & $\mathbf{0}$ & 0 & 5 & 1.6 & 18 & 1.5 \\
\hline
\end{tabular}

Digitizing was available to $1127 \quad(93.8 \%)$ respondents, GIS mapping to 1081 (90.0\%), and GIS data collection/conversion to 1065 (88.7\%) respondents. The finding also shows that the least available GIS services were spatial analysis with 97 (8.0\%) responses; remote sensing 273 (22.8\%); link application of computerized site map, aerial photograph and satellite images 18 (1.5\%); and image georeferencing 315 (26.2\%) responses.

Generally, the availability of services in these Nigerian Universities of technology depended on the availability of facilities, which is in line with the position of Weimer and Pete (2006) who noted that the library service levels vary widely, depending on the nature and priorities of the library systems and campus community. But when compared Tables 4. 3 and 4.4 , we can see that server with $1023(85.2 \%)$ responses was available but the link of application of computerized site map, aerial photograph and satellite image with 18 (1.5) responses was much lower. This may not be unconnected with inability of the server to function well, to meet the need of the users as a result of poor maintenance culture or lack of knowledge on how to use them. GIS database design and software sales recorded no responses showing that these services were not available in any of the selected schools. This may be due to expensive nature of these services or as a result of lack of experts to guide the users on how to explore the services as we may have if the GIS were integrated in the library which would require a GIS Librarian to guide users on GIS operations.

Accessibility to GIS Services in the selected Federal Universities of Technology in Nigeria GIS services are supposed to be accessible in whatever format or means without any factor hindering the user from accessibility. In order to find out the ways and measures taken to facilitate accessibility to GIS services in the selected FUTs in Nigeria, the respondents were asked to indicate by choosing from the applicable options presented in Table 3. 
TABLE 3: Accessibility Of GIS In The Universities

\begin{tabular}{|c|c|c|c|c|c|c|c|c|c|c|}
\hline Nature and ways of access to GIS & FUT & & ATB & Bauchi & FUT & nna & FUT & erri & Total & \\
\hline GIS services is free & $\begin{array}{l}\text { YES } \\
29 \\
(13.1)\end{array}$ & $\begin{array}{l}\text { NO } \\
192 \\
(86.9)\end{array}$ & $\begin{array}{l}\text { YES } \\
333 \\
(100)\end{array}$ & $\mathrm{NO}$ & $\begin{array}{l}\text { YES } \\
149 \\
(44.9)\end{array}$ & $\begin{array}{l}\text { NO } \\
183 \\
(55.1)\end{array}$ & $\begin{array}{l}\text { YES } \\
242 \\
(76.8)\end{array}$ & $\begin{array}{l}\mathrm{NO} \\
73 \\
(23.2)\end{array}$ & $\begin{array}{l}\text { Yes } \\
753 \\
(62.7)\end{array}$ & $\begin{array}{l}\text { No } \\
448 \\
(37.3)\end{array}$ \\
\hline $\begin{array}{l}\text { There are enough metadata to enhance } \\
\text { access to GIS data }\end{array}$ & $\begin{array}{l}174 \\
(78.7)\end{array}$ & $\begin{array}{l}47 \\
(21.7)\end{array}$ & $\begin{array}{l}218 \\
(65.5)\end{array}$ & $\begin{array}{l}115 \\
(34.5)\end{array}$ & $\begin{array}{l}169 \\
(50.9)\end{array}$ & $\begin{array}{l}163 \\
(49.1)\end{array}$ & $\begin{array}{l}98 \\
(31.1)\end{array}$ & $\begin{array}{l}217 \\
(68.9)\end{array}$ & $\begin{array}{l}183 \\
(54.8)\end{array}$ & $\begin{array}{l}542 \\
(45.2)\end{array}$ \\
\hline $\begin{array}{l}\text { Electricity is always available to keep } \\
\text { the GIS operation in department }\end{array}$ & $\begin{array}{l}17 \\
(7.7)\end{array}$ & $\begin{array}{l}204 \\
(92.3)\end{array}$ & $\begin{array}{l}47 \\
(14.1)\end{array}$ & $\begin{array}{l}286 \\
(85.9)\end{array}$ & $\begin{array}{l}97 \\
(29.2)\end{array}$ & $\begin{array}{l}235 \\
(70.8)\end{array}$ & $\begin{array}{l}22 \\
(7)\end{array}$ & $\begin{array}{l}293 \\
(93.0)\end{array}$ & $\begin{array}{l}183 \\
(15.2)\end{array}$ & $\begin{array}{l}1018 \\
(84.8)\end{array}$ \\
\hline $\begin{array}{l}\text { GIS workstation have adequate } \\
\text { hardware to always support the } \\
\text { operations }\end{array}$ & $\begin{array}{l}43 \\
(19.5)\end{array}$ & $\begin{array}{l}178 \\
(80.5)\end{array}$ & $\begin{array}{l}16 \\
(4.8)\end{array}$ & $\begin{array}{l}317 \\
(95.2)\end{array}$ & $\begin{array}{l}143 \\
(43.1)\end{array}$ & $\begin{array}{l}189 \\
(56.9)\end{array}$ & $\begin{array}{l}67 \\
(21.3)\end{array}$ & $\begin{array}{l}248 \\
(78.7)\end{array}$ & $\begin{array}{l}269 \\
(22.4)\end{array}$ & $\begin{array}{l}932 \\
(77.6)\end{array}$ \\
\hline $\begin{array}{l}\text { There are adequate software for GIS } \\
\text { applications in the department }\end{array}$ & $\begin{array}{l}26 \\
(11.8)\end{array}$ & $\begin{array}{l}195 \\
(88.2)\end{array}$ & $\begin{array}{l}55 \\
(16.5)\end{array}$ & $\begin{array}{l}278 \\
(83.5)\end{array}$ & $\begin{array}{l}84 \\
(25.3)\end{array}$ & $\begin{array}{l}248 \\
(74.7)\end{array}$ & $\begin{array}{l}46 \\
(14.6)\end{array}$ & $\begin{array}{l}237 \\
(75.2)\end{array}$ & $\begin{array}{l}211 \\
(17.6)\end{array}$ & $\begin{array}{l}990 \\
(82.4)\end{array}$ \\
\hline $\begin{array}{l}\text { GIS workstations is easily accessible in } \\
\text { the department }\end{array}$ & $\begin{array}{l}48 \\
(21.7)\end{array}$ & $\begin{array}{l}173 \\
(78.3)\end{array}$ & $\begin{array}{l}36 \\
(10.8)\end{array}$ & $\begin{array}{l}297 \\
(89.2)\end{array}$ & $\begin{array}{l}23 \\
(6.9)\end{array}$ & $\begin{array}{l}309 \\
(93.1)\end{array}$ & $\begin{array}{l}57 \\
(18.1)\end{array}$ & $\begin{array}{l}258 \\
(81.9)\end{array}$ & $\begin{array}{l}164 \\
(13.7)\end{array}$ & $\begin{array}{l}1037 \\
(86.3)\end{array}$ \\
\hline $\begin{array}{l}\text { GIS is accessible in the University } \\
\text { loaded on individual workstation }\end{array}$ & $\begin{array}{l}141 \\
(63.8)\end{array}$ & $\begin{array}{l}80 \\
(36.2)\end{array}$ & $\begin{array}{l}171 \\
(51.4)\end{array}$ & $\begin{array}{l}162 \\
(48.6)\end{array}$ & $\begin{array}{l}189 \\
(56.9)\end{array}$ & $\begin{array}{l}143 \\
(43.1)\end{array}$ & $\begin{array}{l}139 \\
(44.1)\end{array}$ & $\begin{array}{l}176 \\
(55.9)\end{array}$ & $\begin{array}{l}640 \\
(53.3)\end{array}$ & $\begin{array}{l}561 \\
(46.7)\end{array}$ \\
\hline $\begin{array}{l}\text { The accommodation of the GIS } \\
\text { workstation in the department is } \\
\text { satisfactory }\end{array}$ & $\begin{array}{l}24 \\
(10.9)\end{array}$ & $\begin{array}{l}197 \\
(89.1)\end{array}$ & $\begin{array}{l}115 \\
(34.5)\end{array}$ & $\begin{array}{l}218 \\
(65.5)\end{array}$ & $\begin{array}{l}103 \\
(31.0)\end{array}$ & $\begin{array}{l}230 \\
(69.3)\end{array}$ & $\begin{array}{l}44 \\
(14)\end{array}$ & $\begin{array}{l}271 \\
(86.0)\end{array}$ & $\begin{array}{l}286 \\
(23.8)\end{array}$ & $\begin{array}{l}915 \\
(76.2)\end{array}$ \\
\hline $\begin{array}{l}\text { The hours of operation of the GIS } \\
\text { laboratory is satisfactory }\end{array}$ & $\begin{array}{l}67 \\
(30.3)\end{array}$ & $\begin{array}{l}154 \\
(69.7)\end{array}$ & $\begin{array}{l}86 \\
(25.8)\end{array}$ & $\begin{array}{l}247 \\
(74.8)\end{array}$ & $\begin{array}{l}81 \\
(24.4)\end{array}$ & $\begin{array}{l}251 \\
(75.6)\end{array}$ & $\begin{array}{l}63 \\
(20)\end{array}$ & $\begin{array}{l}252 \\
(80)\end{array}$ & $\begin{array}{l}297 \\
(24.7)\end{array}$ & $\begin{array}{l}904 \\
(75.3)\end{array}$ \\
\hline $\begin{array}{l}\text { The needed technical assistance is } \\
\text { always received when operating the } \\
\text { GIS }\end{array}$ & $\begin{array}{l}89 \\
(40.3)\end{array}$ & $\begin{array}{l}132 \\
(59.7)\end{array}$ & $\begin{array}{l}45 \\
(13.5)\end{array}$ & $\begin{array}{l}288 \\
(86.5)\end{array}$ & $\begin{array}{l}73 \\
(22)\end{array}$ & $\begin{array}{l}259 \\
(78)\end{array}$ & $\begin{array}{l}44 \\
(14)\end{array}$ & $\begin{array}{l}289 \\
(91.7)\end{array}$ & $\begin{array}{l}254 \\
(21.1)\end{array}$ & $\begin{array}{l}947 \\
(78.9)\end{array}$ \\
\hline $\begin{array}{l}\text { GIS service will be more accessible if } \\
\text { they are in the library }\end{array}$ & 0 & $\begin{array}{l}221 \\
(100)\end{array}$ & $\begin{array}{l}264 \\
(79.3)\end{array}$ & $\begin{array}{l}69 \\
(20.7)\end{array}$ & $\begin{array}{l}256 \\
(77.1)\end{array}$ & $\begin{array}{l}76 \\
(22.9)\end{array}$ & $\begin{array}{l}283 \\
(89.8)\end{array}$ & $\begin{array}{l}32 \\
(10.2)\end{array}$ & $\begin{array}{l}803 \\
(66.9)\end{array}$ & $\begin{array}{l}398 \\
(33.1)\end{array}$ \\
\hline
\end{tabular}

To ensure that they had access to GIS services, 753 $(62.7 \%)$ respondents reported that they were not charged fees. Contrarily, $448(37.3 \%)$ respondents indicated that they were charged fees for GIS services in their Universities. This latter position might not be unconnected with the introduction of fee charges for some sophisticated GIS services such as digitizing, software sales, GIS database design etc. Six hundred and fifty-nine $(54.8 \%)$ respondents indicated that there are enough metadata to enhance their access to the GIS data while 542 (45.2\%) respondents felt there were not enough. In terms of electricity supply to facilitate the operation of GIS in the Department, only $183(15.2 \%)$ respondents felt satisfied while the majority of $1018 \quad(84.8 \%)$ indicated that electricity supply to power GIS laboratories was not always available.

The majority of the respondent, i.e $932(77.6 \%)$ felt there were not enough hardware to support GIS operations but 269 (22.4\%) felt otherwise. For software adequacy, only $211(17.6 \%)$ respondents felt so while the majority of $990(82.4 \%)$ felt the software in use for GIS operations in the departments were not adequate. One hundred and sixty-four $(13.7 \%)$ respondents affirmed that GIS workstations were readily available in the Departments while 1037 $(86.3 \%)$ felt they were not. Six hundred and forty (53.3\%) respondents had access to GIS using individual workstations.

In terms of accommodation and hours of operation of GIS laboratories, $286(12.8 \%)$ and 297 (24.7\%) 
respectively expressed satisfaction. On the contrary, $915 \quad(76.2 \%)$ and $904 \quad(75.3 \%)$ expressed dissatisfaction with accommodation for and hours of operation respectively of GIS laboratories

Most respondents were not provided with technical assistance in the use of GIS as indicated by 947 (78.9\%), with only few respondents, i.e., 254 (21.1\%) indicating that they were provided with the requisite technical assistance in the use of GIS. Most respondents, $803(66.9 \%)$ were of the opinion that if the GIS laboratories were located in the libraries of the universities under study they would be more accessible. On their part, about one third of the respondents, i.e., 398 (33.1\%) felt that GIS services would be more easily accessible outside the libraries.

From the foregoing, the respondents were generally displeased with GIS in terms of software and hardware adequacy, accommodation, access, hours of operation, etc as they are currently being offered in the Departments. This general displeasure could be said to be what is working in favor of the respondents' preference for libraries being where GIS services would be better available.

Awareness of GIS Services among Librarians in the Selected Federal Universities of Technology in Nigeria In order to achieve this some question were asked; table 4 captured the respondents' responses to the questions. TABLE 4: $\quad$ Respondents' Awareness Of GIS Services In The Library

\begin{tabular}{|c|c|c|c|c|c|c|c|c|c|c|c|}
\hline \multirow[t]{2}{*}{ S/no. } & \multirow[t]{2}{*}{ GIS services among librarian } & \multicolumn{2}{|c|}{ FUT Akure } & \multicolumn{2}{|c|}{ ATBU Bauchi } & \multicolumn{2}{|c|}{ FUT Minna } & \multicolumn{2}{|c|}{ FUT Owerri } & \multicolumn{2}{|l|}{ Total } \\
\hline & & YES & $\mathrm{NO}$ & YES & $\mathrm{NO}$ & YES & $\mathrm{NO}$ & YES & $\mathrm{NO}$ & Yes & No \\
\hline b. & $\begin{array}{l}\text { Have prior knowledge of GIS before } \\
\text { now }\end{array}$ & $\begin{array}{l}9 \\
(81.8)\end{array}$ & $\begin{array}{l}2 \\
(18.2)\end{array}$ & $\begin{array}{l}5 \\
(53.6)\end{array}$ & $\begin{array}{l}4 \\
(44.4)\end{array}$ & $\begin{array}{l}11 \\
(78.6)\end{array}$ & $\begin{array}{l}3 \\
(21.4)\end{array}$ & $\begin{array}{l}7 \\
(63.6)\end{array}$ & $\begin{array}{l}4 \\
(36.4)\end{array}$ & $\begin{array}{l}32 \\
(71.1)\end{array}$ & $\begin{array}{l}13 \\
(28.9)\end{array}$ \\
\hline c. & $\begin{array}{l}\text { I'm aware about traditional paper } \\
\text { map library }\end{array}$ & $\begin{array}{l}11 \\
(100)\end{array}$ & 0 & $\begin{array}{l}9 \\
(100)\end{array}$ & 0 & $\begin{array}{l}14 \\
(100)\end{array}$ & 0 & $\begin{array}{l}11 \\
(100)\end{array}$ & 0 & $\begin{array}{l}45 \\
(100)\end{array}$ & 0 \\
\hline $\mathrm{d}$. & $\begin{array}{lll}\text { Through } & \text { Websites/ } & \text { social } \\
\text { networking } & & \end{array}$ & $\begin{array}{l}2 \\
(18.2)\end{array}$ & $\begin{array}{l}9 \\
(81.2)\end{array}$ & $\begin{array}{l}2 \\
(22.2)\end{array}$ & $\begin{array}{l}7 \\
(77.8)\end{array}$ & $7(50)$ & $7(50)$ & $\begin{array}{l}3 \\
(27.2)\end{array}$ & $\begin{array}{l}8 \\
(72.2)\end{array}$ & $\begin{array}{l}14 \\
(31.1)\end{array}$ & $\begin{array}{l}31 \\
(68.9)\end{array}$ \\
\hline e. & Library patron request & $\begin{array}{l}3 \\
(27.3)\end{array}$ & $\begin{array}{l}8 \\
(72.7)\end{array}$ & $\begin{array}{l}5 \\
(55.6)\end{array}$ & $\begin{array}{l}4 \\
(44.4)\end{array}$ & $\begin{array}{l}4 \\
(28.6)\end{array}$ & $\begin{array}{l}10 \\
(71.4)\end{array}$ & $\begin{array}{l}5 \\
(45.5)\end{array}$ & $\begin{array}{l}6 \\
(54.5)\end{array}$ & $\begin{array}{l}17 \\
(37.8)\end{array}$ & $\begin{array}{l}28 \\
(62.2)\end{array}$ \\
\hline f. & $\begin{array}{l}\text { Reading recent literature in GIS and } \\
\text { related field }\end{array}$ & $\begin{array}{l}4 \\
(36.4)\end{array}$ & $\begin{array}{l}7 \\
(63.6)\end{array}$ & $\begin{array}{l}7 \\
(77.8)\end{array}$ & $\begin{array}{l}2 \\
(22.2)\end{array}$ & $\begin{array}{l}6 \\
(48.9)\end{array}$ & $\begin{array}{l}8 \\
(57.1)\end{array}$ & $\begin{array}{l}4 \\
(36.4)\end{array}$ & $\begin{array}{l}7 \\
(63.6)\end{array}$ & $\begin{array}{l}21 \\
(46.7)\end{array}$ & $\begin{array}{l}24 \\
(53.3)\end{array}$ \\
\hline g. & $\begin{array}{l}\text { Attending courses in tertiary } \\
\text { institutions for higher degrees }\end{array}$ & $\begin{array}{l}11 \\
(100)\end{array}$ & 0 & $\begin{array}{l}6 \\
(66.7)\end{array}$ & $\begin{array}{l}3 \\
(33.3)\end{array}$ & $\begin{array}{l}4 \\
(28.6)\end{array}$ & $\begin{array}{l}10 \\
(71.4)\end{array}$ & $\begin{array}{l}10 \\
(90.9)\end{array}$ & $\begin{array}{l}1 \\
(9.1)\end{array}$ & $\begin{array}{l}31 \\
(68.9)\end{array}$ & $\begin{array}{l}14 \\
(31.1)\end{array}$ \\
\hline
\end{tabular}

Table 4 contains the responses of respondents to awareness of GIS services in the library. The findings show that the traditional paper map library has the frequency of $45(100 \%)$, prior knowledge of GIS services in the library before now recorded 32 (71. $1 \%$ ), James (2008) observes that in the past the map library was where students and other researchers would call for maps but now their first place of stop will be the internet. This may have given the librarians the idea of the GIS as paper maps are also part of paradigm shift of the library resources to digital maps which will culminate into GIS services. The awareness of GIS services in the library from attending courses in higher institutions of learning scored $31(68.9 \%)$. Simultaneously, on the order hand librarians who learn about GIS through Websites/ social networking recorded 31 (68.9\%), the low utilization of social network among librarians could be as a result of the technology seems to be new to them and not so common among the librarians therefore there is the need for librarian to embrace the emerging technology to better their skills in the current era Murphy \& Moulaison (2010) observed that the social networking librarian posseses the skills necessary for providing services in and within the online social network site. Library patron request 28 $(62.2 \%)$ and Reading recent literature in GIS and related field scored 24 (53.3\%) responses. Librarians low level of awareness of GIS will not be good for the integration of GIS services into the library. 


\section{Effort of the Libraries in Integrating GIS Services into the Library}

Table 5 shows the responses of the strategies employed by the respondents in order to adopt GIS services into the library of the selected FUTs in Nigeria.

Table 5: Effort being made in Implementing GIS in the Library

Effort being made in implementing GIS in
Organization of workshop, conferences
create awareness
Provide GIS/ICT facilities in the library
Collaboration among departments and org
services in the library
Constant power supply in the library
Awareness of GIS presence in the library
Administrative support
GIS use policy in the library
Technical assistance to GIS users

From table 5 it was discovered that the highest response rate for the strategies to integrate GIS service in FUT Akure includes provision of constant power supply in the library 11 (100\%), constant technical assistance for GIS users 10 (90.9\%), provision of adequate GIS/ICT facilities in the library $9(81.1 \%)$, provision of GIS services policy in the library $8(72.1 \%)$ and organization of workshop, conferences and seminar to create awareness 6 $(54 \%)$. While, creation of awareness of GIS presence $8(72.7 \%)$, solicits for administrative supports 5 (45.6\%) recorded the highest score of the respondents disagree to the strategies for GIS integration into the library.

In ATBU Bauchi, the table revealed that organization of workshop, conferences and seminars to create awareness with 9 (100\%), constant technical assistance to GIS users 9 (100\%), solicits administrative support $8(88.9 \%)$, provision of constant power supply in the library $8(88.9 \%)$, create awareness of GIS services presence in the library 7 $(77.8 \%)$ and provision of constant power supply with $5(55.6 \%)$, were found to be the respondents favorable strategies for the integration of GIS service into the library. On the other hand, collaboration among departments and organizations to support GIS services in the library $6(54.6 \%)$ disagreed by the respondents as the right strategy for integrating GIS services into the library.

More so, at the FUT Minna, the provision of GIS service policy in the library score $14(100 \%)$, constant technical assistance to the GIS users 12 $(85.7 \%)$, provision of constant power supply in the library $14(100 \%)$, Organization of workshop, conferences and seminars to create awareness 11

\begin{tabular}{|c|c|c|c|c|c|c|c|c|c|}
\hline \multicolumn{2}{|c|}{$\begin{array}{l}\text { FUT } \\
\text { Akure }\end{array}$} & \multicolumn{2}{|c|}{$\begin{array}{l}\text { ATBU } \\
\text { Bauchi }\end{array}$} & \multicolumn{2}{|c|}{$\begin{array}{l}\text { FUT } \\
\text { Minna }\end{array}$} & \multicolumn{2}{|c|}{$\begin{array}{l}\text { FUT } \\
\text { Owerri }\end{array}$} & \multicolumn{2}{|c|}{ Total } \\
\hline $\mathrm{F}$ & $\%$ & $\bar{F}$ & $\%$ & $\mathrm{~F}$ & $\%$ & $\mathrm{~F}$ & $\%$ & $\bar{F}$ & $\%$ \\
\hline 6 & 54 & 9 & 100 & 11 & 78.6 & 7 & 63.6 & 33 & 73.3 \\
\hline 9 & 81.1 & 3 & 33.3 & 8 & 57.1 & 10 & 90.9 & 30 & 66.7 \\
\hline 4 & 36.3 & 3 & 33.3 & 9 & 64.3 & 4 & 36.3 & 20 & 44.4 \\
\hline 11 & 100 & 8 & 88.9 & 14 & 100 & 10 & 90.9 & 43 & 95.6 \\
\hline 2 & 18.1 & 7 & 77.8 & 6 & 42.9 & 7 & 63.6 & 22 & 48.9 \\
\hline 6 & 54.5 & 8 & 88.9 & 6 & 42.9 & 5 & 45.5 & 25 & 56 \\
\hline 8 & 72.7 & 6 & 54.6 & 14 & 100 & 8 & 77.7 & 36 & 80 \\
\hline 10 & 90.9 & 9 & 100 & 12 & 85.7 & 10 & 90.9 & 41 & 91.1 \\
\hline
\end{tabular}

(78\%), collaboration among departments and organizations to support GIS service in the library 9 $(64.3 \%)$ and provision of constant power supply in the library $7(50 \%)$ were agreed by the respondents as the main strategies to be adopted by the federal university of technology Minna.

Similarly, in FUT Owerri, the provision of adequate GIS/ICTs facilities in the library 10 (90.9\%), constant technical assistance to GIS user 10 $(90.9 \%)$, provision of constant power supply in the library $10(90.9 \%)$, provision of GIS services users' policy in the library $8(77.7 \%)$ adequate Organization of workshop, conferences and seminars to create awareness 7 (63.6\%), create awareness of GIS presence in the library $7(63.6 \%)$ respectively, the respondents agreed to as the main strategies for the integration of GIS services into FUT Owerri library, whereas, collaboration among departments and organizations to support GIS services $6(54.5 \%)$ was disagreed among the respondents as commensurable strategy for GIS integration into the library.

Generally, looking at the facial value for the Federal Universities of technology Libraries the findings shows that constant electrification or power supply topped with $43(95.6 \%)$ as shown the table 4.11, this finding is in line with Abumere and et al (1997), who affirmed that the major problem with technology development in Nigeria is erratic power supply. The fear of erratic power supply due to shortage is the major strategy that every library that wants to succeed in the ICT era will have settle before embark on any digital services in the library, because nothing will function if the power to supply energy to all the GIS gadget is not available. Though the installation of generator with a capacity high enough to carry all the systems in the library, such additional equipment makes setting up and operating 
a GIS much more expensive than would otherwise have been the case, this goes to show that in our part of the world where power supply is always the problem we shall always have difficulties in providing this services in our libraries.

Constant technical assistance to GIS users is also agreed strategy for GIS integration into the library, this is because it has the second highest number of respondents of $41(91.1 \%)$ who all agreed to it, this may be due to the believe that the librarians have that because of the assistance they granted users of the library always attract them to use the library resources. Among the unpopular strategies is the collaboration among departments and organization to provide GIS service in the library with 21 (44.4\%) this contradicts Shuler \& Obermeyer, 2001, who discovered that Libraries are centers for collaboration and have links across campus and into the community beyond. The implication of this is that the library being an autonomous organ can on it own provide GIS services without collaboration with the Departments in the University.

\section{Summary of the Findings}

From the data collected and analyzed in this study, the following were the summary of the major findings:-

1. There are available computer hardware units for GIS operation however, some peripherals like plotters and scanner were less available generally from the selected Federal Universities Technology in Nigeria; ArcView was the type of GIS software available among the selected FUT and more so, spatial and image analyst, land view IV, community 2020 were some of the GIS soft ware that was not too popular among the selected Federal Universities Technology in Nigeria; Full-time employee and paraprofessional's staff were the once in charge of most of the GIS services in the selected though; there were presence of professionals in some of the universities and Map data format, attribute data, raster data format and graphics were feature more prominent types of GIS available among the GIS users in the selected Federal Universities Technology.

2. Digitizing, GIS mapping, GIS data collection/conversion and GIS training were the available GIS services. However, soft ware sales, link application of computerized site map, aerial photograph and satellite image, spatial analysis, image georeferencing, remote sensing services were less or not available in the selected FUTs in Nigeria.

3. GIS services were provided from the departments such as the geo-informatics, Urban and Regional Planning. GIS services were neither provided from the library nor the MIS department of the selected university; GIS users mostly preferred the library to provide GIS services; The conditions for the accessibility of GIS services from the various departments were not favorable to the GIS users, but they will be more accessible with favorable conditions if they are in neutral location like the library, which is the hub of information in the campus.

4. Digitizing, data collection/conversion, GIS mapping, scanning and GIS training are the services that is highly utilized on the order hand, image georeferencing, spatial analysis, link application computerize site map, aerial photograph and satellite image remote sensing, GIS database design and software sales were not utilized by the users of GIS services in the selected FUT.

5. The librarians in the selected FUTs are aware of GIS service in the library.

6. Provision of constant power, adequate GIS/ICT facilities, needed technical assistance for GIS user and collaboration among organizations, departments and various units in the school to support GIS services in the library were the main strategies for the integration of GIS services into the library.

\section{Conclusion}

The analysis and summary of this finding revealed that GIS services are available in the departments, and the services available are GIS mapping, digitizing, and data collection/conversion while, services such as link application of computerized site map, aerial photograph and satellite image service were less available, GIS data design, soft ware sales and remote sensing services were partially not available. Mostly, the conditions for GIS access were not too favorable to the GIS user since they are located in the department. Therefore, given the level of GIS awareness among the librarian and the neutrality of library functionality as information hub in the campus it is natural that the authority give the necessary support to bring in this service into the library, as it was indicated by the respondents as the most preferred location in the university to provide 
GIS service, where a librarian with GIS skill (GIS librarian) will be dedicated to the provision of the needed assistance to the library patron to maximized access and utilization of GIS services.

\section{Recommendations}

The following recommendations are offered so as to improve GIS services in the Federal Universities of Technology in Nigeria:

1. The university library should collaborate with organizations that deal with spatial information or GIS related departments in the university to facilitate GIS services integration into the library, to acquire, store data from various agencies in a centralized location for maximum accessibility and utilization.

2. The parent organization should allocate more funds to the library to enable them respond to the state of GIS facility and train manpower

3. With a trained GIS librarian in the library he/she will be able to train the patron (GIS user) on some of the sophisticated services that presently not utilized form the department such as GIS data design, remote sensing, and link application to computerizes site map, aerial photograph and satellite image.

\section{References}

Abbott, L. T. and Carolyn D. A. (1995). "GIS: a new component of public service." Journal of Academic Librarianship 21(4): 251-256

Abumere, S., Areola, O. O., and Ayeni, O. A. (1997). "Model GIS Laboratory For Higher Education in a Developing Country: The Example of The University of Ibadan, Nigeria." Retrieved on $20^{\text {th }}$ January 2010 from http://www.ncgia.ucsb.edu/conf/gishe97

ARL/GIS Participant Roster. (2001). Retrieved \begin{tabular}{lll} 
February $\quad 01, \quad 2010 \quad$ from \\
\hline
\end{tabular} http://www.arl.org/info/gis/roster.html

Association of Research Libraries (ARL) (1999) the ARL Geographic Information Systems Literacy Project. SPEC KIT 238 Washington, D C: Association of Research Libraries.

Aufmuth, J. (2006) "centralized vs. Distributed Systems: Academic Library Models for GIS and Remote Sensing Activities on Campus." (in special issue on Geographic Information Systems and Libraries), Library Trends 55(2)236-253.
Cheverie, J. (1995). Getting started: Ready, set...get organized! Journal of Academic Librarianship, 21(4), 292.

Cox, A. B. (1995) "An Overview to Geographic Information Systems": Journal of Academic Librarianship 21 (4) July 1995, pp.237-249.

Deckelbaum, D. \& Bruman, H. J. (1999). GIS in libraries: An overview of concepts and concerns. Issues in Science and Technology Librarianship, 21(Winter 1999), 02-10-06. Retrieved February 01, 2010 from http://www.istl.org/99winter/article $3 . h t m l$

DeMers, M. N. (1997). Fundamentals of Geographic Information Systems. New York: John Wiley and Sons.

Derksen, C. R. M. and et al (2007). The Place of Geographic Information System Services in a Geosciences. Information Center. Accessed on $24^{\text {th }}$ December, 2009 from $w w w$ sul.stanford.edu/staff/pubs/GeoscienceIS.pdf

Gabaldón, C. and John R. (2006) "GIS and the Academic Library: A Survey of Libraries Offering GIS Services in Two Consortia", Issues in Science \& Technology Librarianship 48, Fall 2006, pp.1320. Retrieved February 01, 2010 from [http://www.istl.org/06-fall/refereed.html]

Garza, E. (2006) Rice University's GIS/Data Center: How do we do GIS? Retrieved on $13^{\text {th }}$ December, 2009 from proceedings.esri.com/library/userconf/educ06/pa pers/educ_1626.pdf

Goodchild, M. F. (1998) "The Geolibrary: "in Carver S. and Openshaw (Eds) Innovations in GIS. 5. London: Taylor and Francis pp 59-68.

Goodchild, Michael F.,(2010). Twenty years of progress: GIScience in 2010. Journal of Spatial Information Science 1 pp. 3-20 doi: 10. 5311/ JOSIS.2010.1.2. July 27, 2010.

Howser, M. \& Callahan, J (2004) A Geographic Information Systems (GIS) handout for 2004 New Faculty GIS Services paper Retrieved February 01, 2010 from; drupal.michaelhowser.com/node/12 PDF

Kollen, C. and Charlene B. (1993)"'Automation and Map Librarianship: Three Issues'", Bulletin [Special Libraries Association, Geography and Map Division] 173, September 1993, pp.24-38.

Kowal, K. C. (2002) "Tapping the Web for GIS and Mapping Technologies: For All Levels of Libraries and Users", Information Technology and Libraries 21 (3): 109-114.

Larsgaard, M. L. and Larry C. (1995) "Accessing Spatial Data Online: Project Alexandria", Information Technology and Libraries 14 (2) 93- 
97. Abstract Retrieved September 17, 2009 from [http://www.lita.org/ital/ital1402.html\#anchor1396 83]

McGlamery, P. (1995) "Building the Virtual Map Library: Some Considerations", Cartographic Perspectives 21, spring 1995: 24-28

Mohammed, Zakari (2006). The library and information in Nigerian Universities: an inaugural lecture.
Rasheed, Y. (2005) GIS Education in Nigeria: the example of GIS Program of the University of Ibadan in Nigeria, GIS Unit, Department of Geography, University of Ibadan. Ibadan, Nigeria Stone, J. (1999) "Stocking Your GIS Data Library". Issues in Science and Technology Librarianship 21, Winter 1999. [http://www.library.ucsb.edu/istl/99winter/article1.html] 